Mikhail M. Verholantsev

art historian, graphic artist

Corresponding Member of the Russian Academy of Arts

e-mail: misolga@yandex.ru

Moscow, Russia

ORCID 0000-0001-6867-2493

DOI:10.36340/2071-6818-2020-16-3-71-79

\title{
THE PHILOSOPHY OF DRAWING
}

Summary: Drawing is a peculiar phenomenon of human civilization. This inexhaustible engine of progress usually seems to us as a kind of study, as a preparation for a painting or a sculptural work.

This essay proposes to look at drawing as a graphic reflection of fantasy, project and intention, a reflection of firm knowledge or doubt and skepticism, and, finally, offers to look at drawing as a method of studying life.

The article provides a brief overview of the stylistic metamorphoses of European drawing, which occurred naturally or by chance.

A person who always draws consciously composes, and his composition involuntarily reflects the scheme of the universe, drawn up in the artist's head based on his or her life experience. Every person has this experience, this worldview, this self-professed philosophy, but only a draftsman can show it.

Collecting drawings is the most difficult and most impressive of all types of collecting. A drawing-lover discovers the whole world, the most accurate description of the given period of civilization.

Since prehistoric times, civilization has been indebted to drawing. The rock drawing of primitive people reflects their vital desires and beliefs.

Afterward, the wheel was designed; the steam engine, electricity, aeronautics were invented, space exploration began... and drawing and drafting accompanied all this.

While developing and becoming mature, people gradually draw up the scheme of the universe in their minds. They are self-professed philosophers themselves; this world order is their faith, moral, ethical, and aesthetic basis. They do not confide their credo to anyone; however, an artist does share, involuntarily expresses it, illustrating it with his or her works. The artist's views on the construction of the universe are most clearly shown in his or her drawings.

If you look at the world around us - at houses, bridges, cars, furniture, dishes, clothes, lighting fixtures... at everything, you need to imagine that it was all designed with a pencil or pen. In other words,
Teaching drawing in schools and universities is teaching the methodology of studying nature. From an early age, a person is taught to draw from life, and this is a visual study of an object. The teacher's task is to show not only to sketch the visible outlines of an object but also to penetrate its structure, in other words, to prepare to fantasize and invent. Meanwhile, in schools and universities, it has become a custom to draw imitating photography as much as possible. Photography is the most democratic way of depicting; however, it is only a one-time, random image of an event. Drawing, on the other hand, accumulates several things. A metaphor, conclusion, knowledge, or ignorance, the struggle against victories and defeats, doubts, and confidence appear involuntarily in a drawing.

Drawing is action, movement of thought, and religious beliefs, whereas photography is stagnant. However, it is precisely this stagnation, rigidity that is cultivated by fashionable modern artists. Moreover, adherents of photorealism develop the ridiculous coincidences so often found in photographs.

Sculptors, architects, and jewelers make the most exciting drawings. Sculptors seem to see through an object, like an X-ray. They want to show volume on a plane. Architects imagine the organization of space and the interaction of volumes. All these aspirations, all these fantasies make drawing uniquely expressive and intelligent.

Keywords: artist, drawing, styles, philosophy, photography

the entire civilization owes its development to drawing, to this engine, motor, laborer, and at the same time designer. Here is a table at which a man is sitting; after all, every sidebar, every coak, is drafted and then drawn. The helicopter invented by Sikorsky was first drawn; one can imagine how the inventor was thoughtfully studying Leonardo's drawings...

Now let's turn to an artist who draws. One examines nature, admires it, tries to understand its design, its system. The drawing is nervous and confusing. The proportions of the depicted object are interpreted very subjectively. However, this drawing 


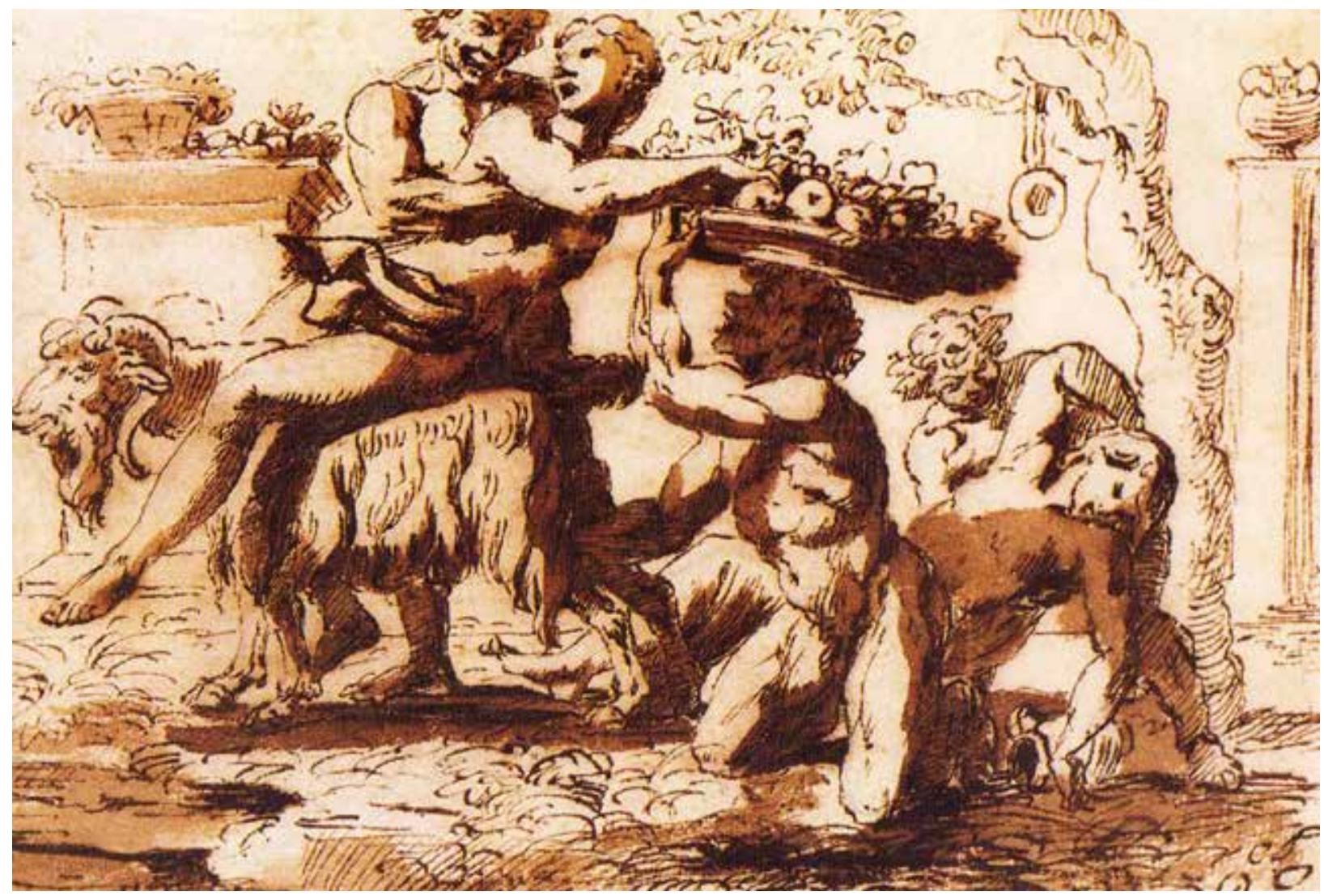

Nicolas Poussin. 1636 Bacchanalia.

fascinates the viewer with the picture of its struggle with victories and defeats.

Innocently, with slavish obedience, another draftsman copies nature. He or she will never make a mistake in proportions, continually checking with a pencil holding in the outstretched hand. He or she carefully captures shades and falling shadows, all reflexes, and tonal relationships. He or she wants to get as close to photography as possible. Naturally, everyone likes such a drawing since photography, and its three-dimensionality is the most democratic, understandable way of depiction.

Yet, the pedagogical practice has discovered that a student who has so long and so carefully worked on photography, as a rule, will not remember anything for future professional practice. However, a student who has drawn a muddle instead of indicative realism can repeat the drawing without looking at nature.

Thus, imagination or appearance, knowledge of an object, or contemplation of it are the methods of drawing that interest us.
Everyone knows the classic settings for drawing from nature. They have always been focused on the grandeur of future historical paintings. Russian artists rushed to catch up with the West, with its three-dimensionality of images, rejecting the ageold traditions of the eastern planar artistic system. "... The Last Day of Pompeii became the first day for the Russian brush...", wrote the enthusiastic poet, as if we had neither Levitsky, nor Rokotov, nor Venetsianov. History often makes fun of past fashion trends; only fifty years after the general admiration for Bryullov's illusory nature, Europe would be carried away by Japanese xylography, which is fundamentally planar. The Art Nouveau style is a triumph of decorative two-dimensionality in the depths of this style, constructivism was born, followed by destruction and non-objectiveness. Drawing, mainly architectural, clearly and expressively demonstrates the development, youth, maturity of the style, and its decadence.

Nevertheless, let's get back to drawing three-dimensionality, even to Caravaggism... 


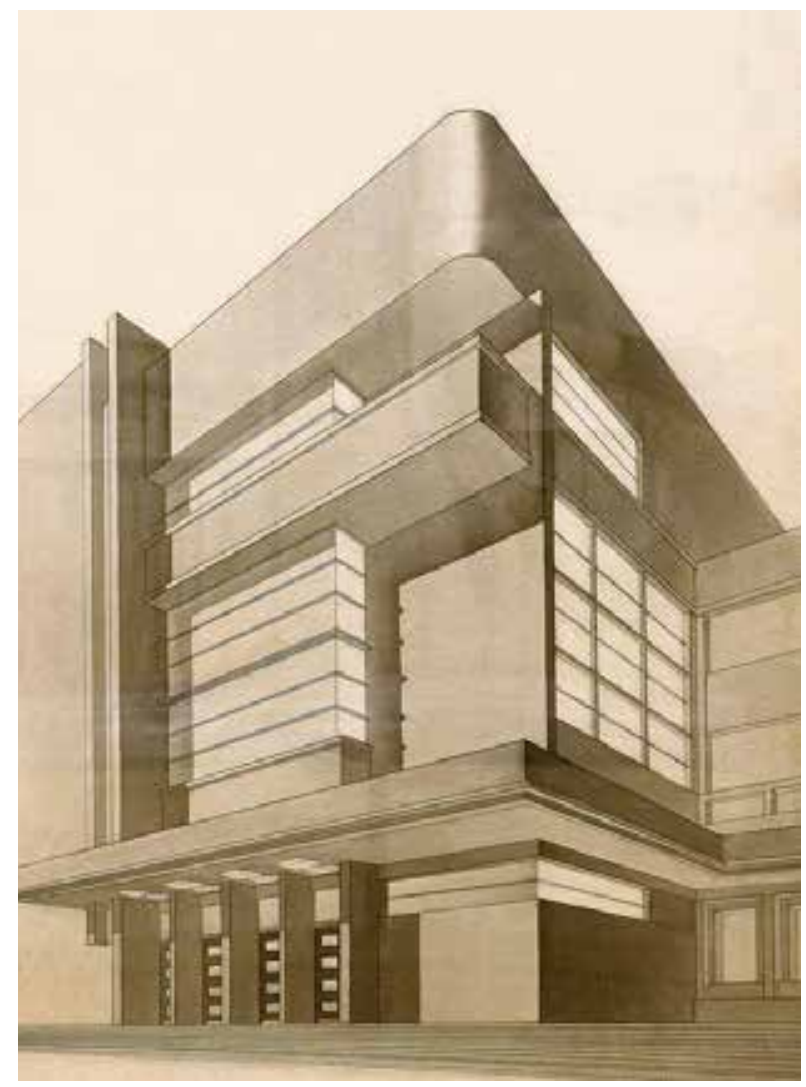

Architect A. V. Shchusev. Project of the main entrance to the State Lenin Library

Nicolas Poussin complained: "Caravaggio came to kill art". Is he right? After all, excellent draftsmen were caravaggists: Jusepe de Ribera, Rembrandt, Gentileschi - father and daughter, Matthias Stomer, Guercino... Though, in their works, they all used chiaroscuro not as an end in itself but as a secondary, auxiliary means of expressiveness.

Stunned and dazzled by his discovery, Caravaggio did not care about the linear beauty of the drawing; however, he sought the photo effect with inspiration. All kinds of visual absurdities lie in wait for every draftsman striving for photography. Take a look at the famous The Entombment of Christ in the Vatican.

Pharisee Nicodemus's muscular legs seem to be the legs of Mary Kleopova, whose right hand is absurdly crowning the head of another Mary. The arrangement of the hand of the Virgin Mary with the head of St. John is even more unsuccessful. However, it is this work of Caravaggio that is considered the pinnacle of his work. Many painters were inspired by this painting, for example, Rubens and Cezanne. Epicurean and hedonist Rubens, the complete opposite of cynicist and ruthless realist Caravaggio, quite freely copied the great canvas and, we note, instinctively avoided the blunders listed

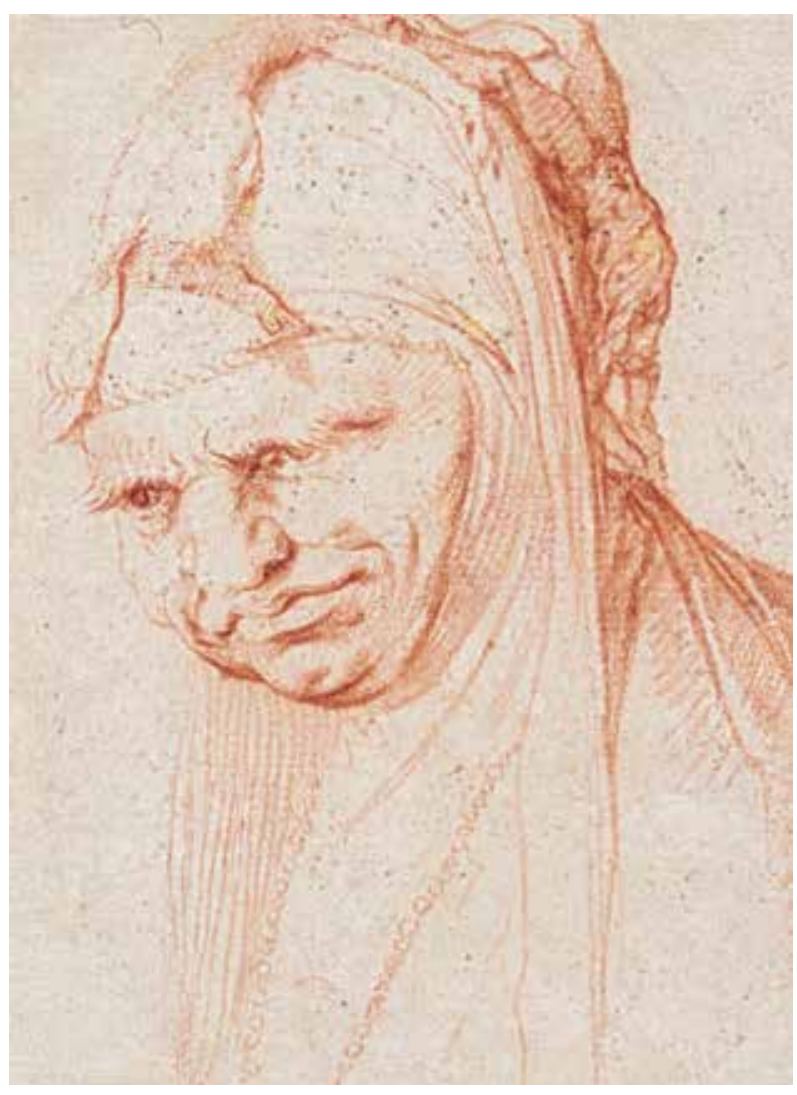

Ingres. Portrait of a Man. 1814

above. He avoided them precisely because he cared about the planar nature of the drawing, and since he was a true Baroque artist with his galactic twists.

Protestant and reformer Caravaggio worked during the Mannerist era, the style of the Catholic Counter-Reformation. Simple techniques of composition, developed by that time, were ignored by him. He contrasts agitated tension of figures, characteristic of the Mannerists, with the "natural" roughness. The compositional scheme familiar to reformer Caravaggio is as follows: on the densely dark rectangle of the canvas, fragments of bodies and draperies are sharply illuminated in different places. These fragments jump out of the darkness so spontaneously and inconsistently with the edges and corners of the picture that one cannot expect consonance for the eyes.

However, an ordinary viewer is so fascinated by the convincingly sharp sculpting of forms, the illusion of chiaroscuro, the cruel realism of the cut heads that he or she is ready to give a rebuff to any aesthetic criticism, even criticism of Nicolas Poussin himself. Is Poussin right or wrong? Did he foresee the future crisis of verism?

It should be noted that European fine art went through a series of democratic revolutions: the re- 


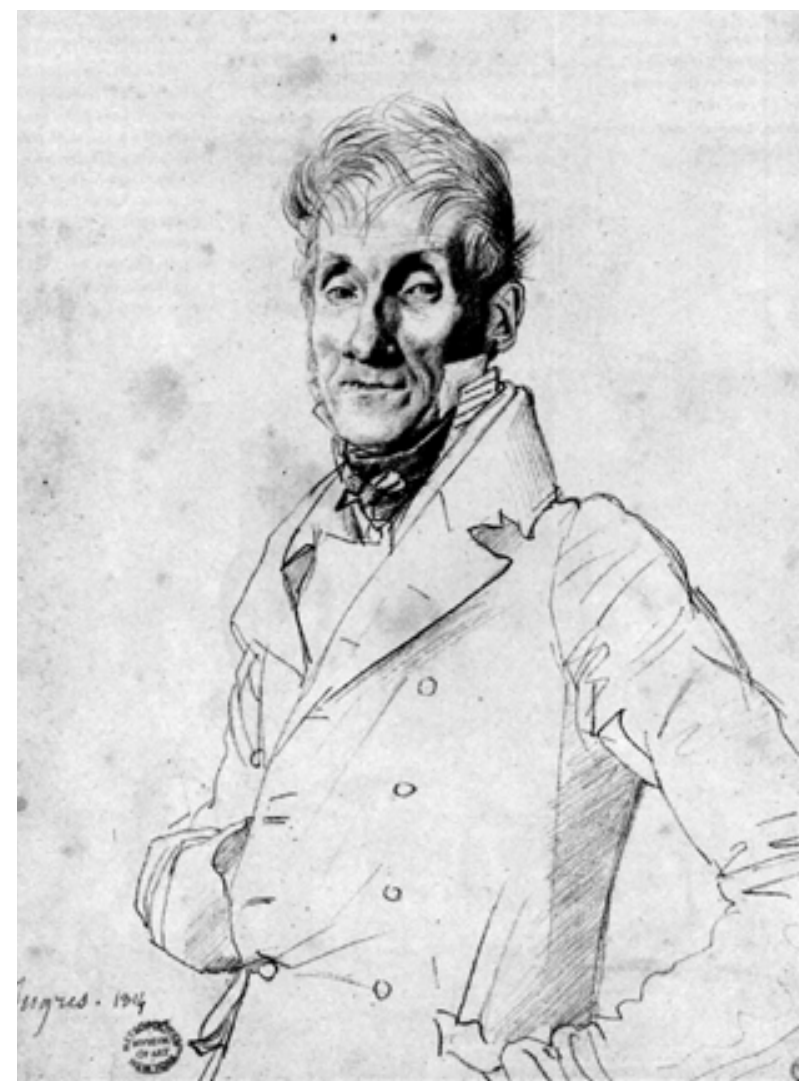

Ingres. Portrait of a Man. 1814.

jection of the Byzantine planar system, Caravaggism, the Camera obscura of Fabrizio and Vermeer, Delacroix's realism, and the invention of photography. The peak of verism came simultaneously with pompiers and salons. The reaction, the desire for radical changes and stylistic renewal, was expressed first in a passion for Japanese engraving and impressionism, then in dandyism and modernism. As mentioned above, constructivism was born in the depths of modernity. Passion for Black and oceanic sculpture finally threw off the fetters of realism. Revolutions that were by no means democratic followed: Dadaism, aestheticizing the absurdity and preposterousness of various kinds, a close relative of Surrealism, metaphysics, Futurism, Rayonism; destruction reigned... In short, numerous and varied types of the Avant-garde appeared.

German Expressionism greatly influenced Soviet artists, especially graphic artists, since the xylography boom of the early $20^{\text {th }}$ century simultaneously swept three revolutionary countries: Russia, Germany, and Mexico. In 1928, Max Beckmann, one of the leading painters of German Expressionism, published his Six Sentences in Painting. Here are two excerpts from this work that accurately characterize his method: "Changing the visual sensation of the

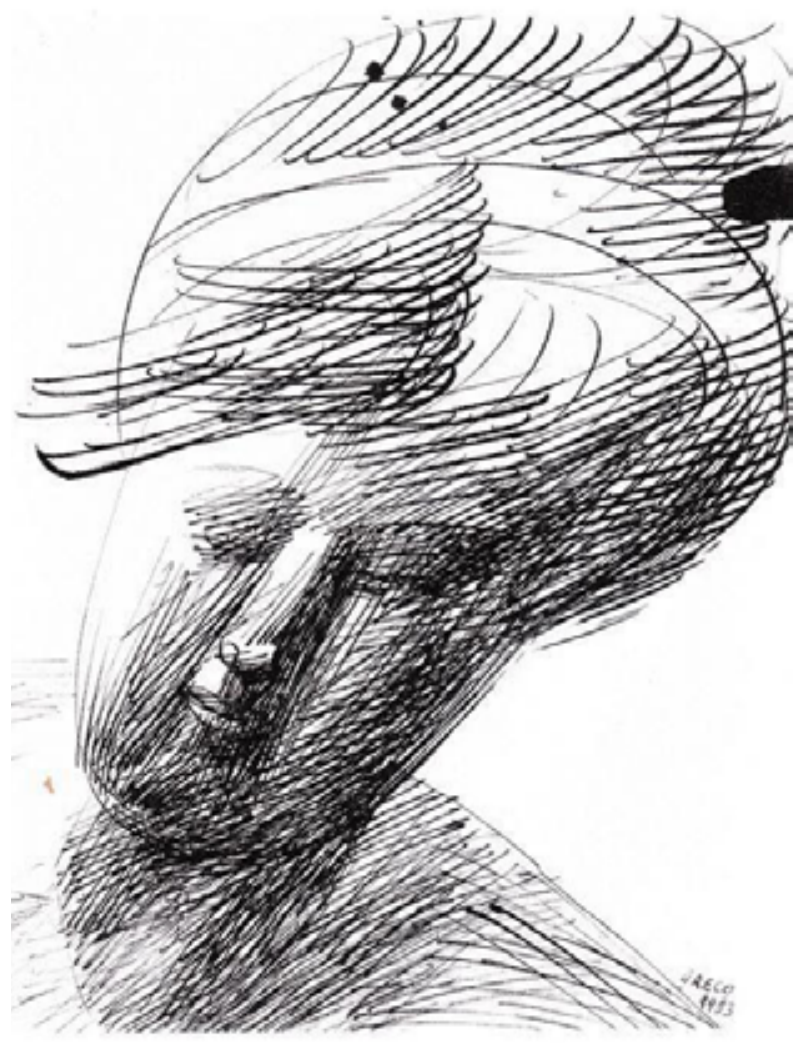

Emilio Greco. Sculptor's Drawing. 1953

world of an object with the help of the transcendental mathematics of the subject's soul determines the construction of the picture... The transfer of the three-dimensional space of the object's world into a two-dimensional plane in the picture is a sign of a true form...." However, non-objectiveness, abstraction had reigned in the spheres of fine art for a long time and despotically, declaring any figurativeness to be something indecent.

This situation could not but provoke a response. The Novecento protest movement emerged from Italian Futurism, and New Materiality emerged from German Dadaism. Both movements declared cultural nationalism based on the historical values of the art of the past centuries. Both of these movements were the parents of our Socialist Realism, a powerful style mistakenly considered the property of the Soviet Union only, while it had spread throughout Europe.

In turn, this style was ridiculed and mocked by Russian non-conformists to the thunderous applause of the "Free World". All the innovations of underground artists were very epigonous; however, they kept a sharp eye on what was happening in the West in the field of visual arts. After all, they introduced a kind of style that I would call "shaggy" into 


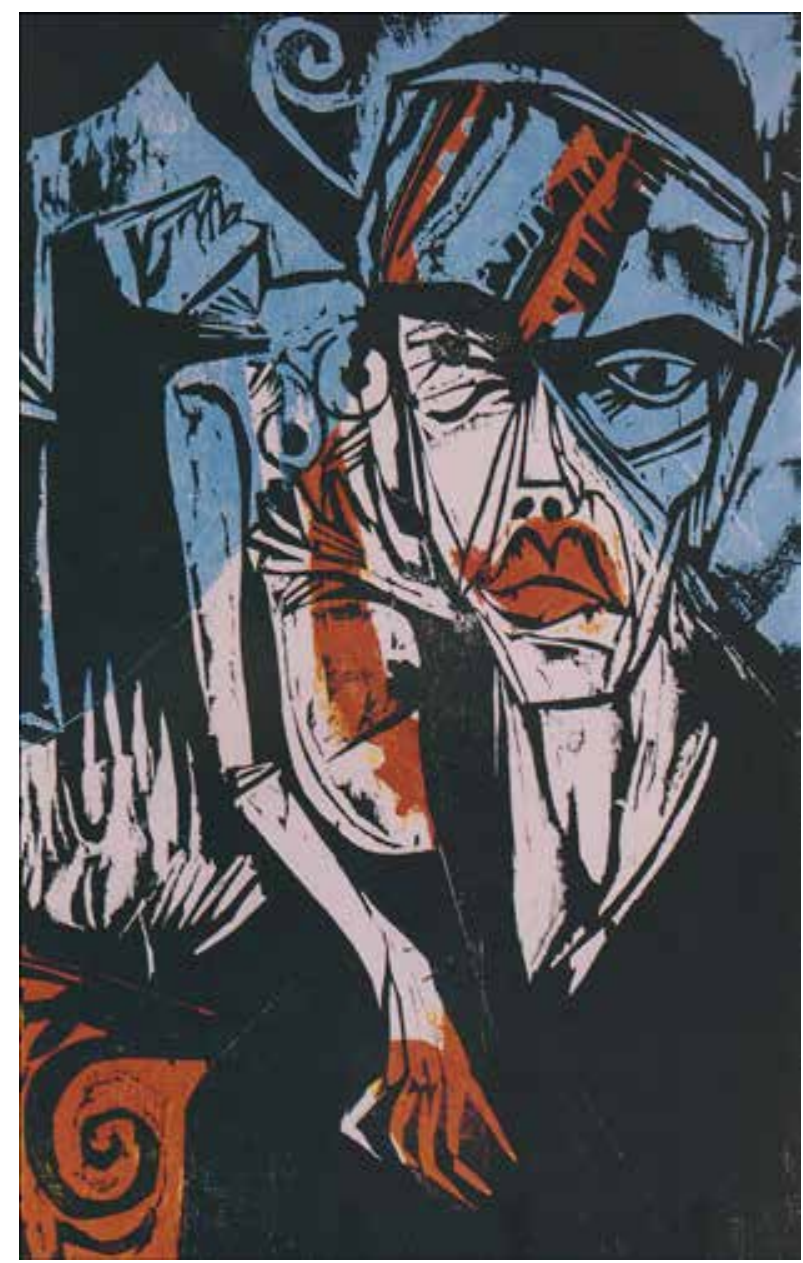

E. Kirchner. 1915. Conflict. Colored longitudinal three-board woodcut our graphics. It is a fusion of Jean Carzou's graphics, with his quivering movements of the pen, Tadeusz Kulisiewicz's pen drawings, and Rembrandt's drawings. D. Lyon was the principal representative of this fashionable style, and today, Y. Perevezentsev and A. Antonov demonstrate it.

Nowadays we are witnessing two main trends in world drawing: non-objectiveness (mainly American abstract expressionism) and photorealism. Very fashionable are grandiose portraits drawn with a pencil with incredible care so that every pore of rough skin does not escape the importunate pencil. The practical function of the grandiose drawing is entirely incomprehensible. Was Poussin right?

My firm conviction as a draftsman is that one should not be ashamed of Beauty, transcendental, timeless, even pretentious Beauty, the beauty of knowledge, and smart drawing.

\section{REFERENCES}

1. 1000 Dessins de Genie. Parkstone International Publ.; 2014.

2. Hodler Ferdinand: Eine Symbolistische Vision. Kunstmuseum Bern. Hatje Cantz Publ.

3. Catalogue ARS LONGA. Creative Union of Artists of Russia. Russian Academy of Arts. Moscow, 2010.

4. Hill, J. 2006. "Drawing research", The Journal of Architecture, vol. 11, no. 3, pp. 329333. DOI: $10.1080 / 13602360600931342$
5. Elrabaie, Ihsan. 2020. "The Graphic Label Was Raised as a Visual Means of Communication to the Values and Behavior of the Individual", International Journal of Art and Art History, vol. 8, no. 1, pp. 1-6. DOI: 10.15640/ijaah.v8n1a1

6. Heck, K. 2018. "Buildings, Portraits and Trees. The University Landscape of Greifswald in Pomerania Caspar", Baltic Journal of Art History, vol. 16, pp. 5-14. DOI: https://doi.org/10.12697/BJAH.2018.16.01 


\section{ФИЛОСОФИЯ РИСУНКА}

Аннотация: Рисунок - это удивительное явление человеческой цивилизации, этот неутомимый движок прогресса представляется нам обычно как некая штудия, как подготовка к живописному или скульптурному произведению.

Это эссе предлагает взглянуть на рисунок как на графическое отражение фантазии, проекта и замысла, отражение твёрдого знания или сомнения и скепсиса и, наконец, предлагает взглянуть на рисунок как на метод исследования натуры.

В статье даётся краткий обзор стилистических метаморфоз европейского рисунка, происходивших закономерно или по воле случая.

Рисующий человек всегда сознательно компонует, а его композиция непроизвольно отражает схему мироздания, выстроенную в голове художника на основе его жизненного опыта. Этот опыт, это мировоззрение, эта доморощенная филойсофия есть у каждого человека, но только рисовальщик способен опубликовать её.

Коллекционирование рисунков - самое трудное и самое интересное из всех видов собирательства. Любитель рисунка открывает для себя целый мир, самую точную характеристику данного отрезка цивилизации.

С доисторических времён цивилизация была обязана рисунку. Скальный рисунок первобытного человека отражает его насущные желания и верования.

Но вот колесо изобретено, изобретен паровой двигатель, электричество, воздухоплавание, началось освоение космоса... и всё это сопровождалось рисунком и чертежом.

Всякий человек, развиваясь и мужая, постепенно выстраивает в своём сознании схему мироздания. Он сам себе доморощенный философ, эта схема мироустройства - его вера, его нравственная, этическая и эстетическая база. Но он никому не поверяет своего кредо, а художник поверяет, невольно излагает, наглядно, именно своими работами. Эти воззрения художника на конструкцию вселенной яснее всего излагаются в его рисунках.
Преподавание рисунка в школах и вузах - это обучение методологии исследования природы. Человека с малых лет учат рисованию с натуры, а это визуальное исследование предмета. Задача педагога научить не просто срисовывать видимые очертания предмета, а ещё и проникнуть в его конструкцию, иными словами, научить фантазировать и изобретать. Между тем, обычаем в школах и вузах стало рисовать, максимально имитируя фотографию. Фотография есть самый демократичный способ изображения, но она лишь одномоментное, случайное изображение события. Рисунок же аккумулирует в себе сумму моментов. В рисунке невольно появляется метафора, умозаключение, знание или незнание, борьба с победами и поражениями, сомнения и уверенность.

Рисунок - это кипение жизни, движение мысли, религиозные воззрения, в то время как фотография - это застылость. Но именно эту застылость, закостенелость и культивируют современные модные художники. Более того, приверженцы фотореализма культивируют нелепые случайности, так часто встречающиеся в фотографиях.

Самые интересные рисунки мы наблюдаем у скульпторов, архитекторов и ювелиров. Скульпторы как бы просвечивают предмет насквозь, словно рентген. Они хотят на плоскости показать объём. Архитекторы представляют себе организацию пространства и взаимодействие объёмов. Все эти стремления, все эти фантазии и делают рисунок особенно выразительным и умным.

Ключевые слова

Художник, рисунок, стили, философия, фотография.

Если взглянуть на окружающий нас мир, на дома, мосты, машины, мебель, посуду, одежду, осветительную арматуру... на всё, то надо думать, то следует представить себе, что это всё проектировалось карандашом или пером. Иными словами, вся цивилизация обязана своим развитием рисунку, этому движку, мотору, чернорабочему и одновременно проектировщику. Вот стол, за которым сидит человек; ведь каждая царга его, каждый шип были нарисованы, а потом вычерчены. 
Вертолёт, изобретённый Сикорским, был сначала нарисован, и можно себе представить, что изобретатель задумчиво рассматривал рисунки Леонардо..

А теперь обратимся к самому художнику, который рисует. Один впивается глазами в натуру, любуется ею, он силится понять её конструкцию, её устройство. Его рисунок нервный и сбивчивый. Пропорции изображаемого объекта трактуются очень субъективно. Но зрителя этот рисунок завораживает картиной борьбы с её победами и поражениями.

Другой рисовальщик простодушно, с рабской покорностью копирует натуру. Он никогда не ошибётся в пропорциях, постоянно проверяя себя карандашом на вытянутой руке. Он тщательно отделывает все собственные и падающие тени, все рефлексы и тональные отношения. Он желает максимально приблизиться к фотографии. Естественно, такой рисунок нравится всем, потому что фотография, её трёхмерность суть самые демократичные, всем понятные способы изображения (рис. 1a).

Педагогическая практика, однако, обнаруживает, что студент, так долго и так тщательно трудившийся над фотографией, как правило, ничего не зафиксирует в своей памяти впрок, для будущей профессиональной практики. А ученик, нарисовавший сумбур вместо показательного реализма, может повторить рисунок, не глядя на натуру.

Итак, мнимость или видимость, знание предмета или созерцание его - таковы интересующие нас методы рисования.

Всем известны классические натурные постановки. Они всегда были ориентированы на грандиозность будущих исторических картин. Русские художники бросились догонять Запад, с его трёхмерностью изображений, отринув вековые традиции восточной плоскостной изобразительной системы. «...Последний день Помпеи стал русской кисти первым днём...» - писал восторженный поэт, словно не было у нас ни Левицкого, ни Рокотова, ни Венецианова. История часто высмеивает прошлые модные тенденции; не пройдёт и пятидесяти лет после всеобщих восторгов от Брюлловской иллюзорности, как Европа увлечётся японской ксилографией, принципиально плоскостной. Стиль МОДЕРН - это торжество декоративной двухмерности, а в недрах этого стиля зародился конструктивизм, за ним последуют деструкция и беспредметность. Рисунок, особенно архитектур- ный, наглядно и выразительно демонстрирует развитие, молодость, зрелость стиля и его декаданс

Но возвращаемся к рисованию трёхмерности, даже к караваджизму...

Никола Пуссен сетовал: «Караваджо пришёл, чтобы убить искусство». Прав ли он? Ведь караваджистами были превосходные рисовальщики: Хусепе Рибера, Рембрандт, отец и дочь Джентиллески, Матиас Стомер, Гверчино... Правда, все они использовали в своих произведениях кьяроскуро не как самоцель, но как побочное, вспомогательное средство выразительности.

Сам же Караваджо, оглушённый и ослеплённый своим открытием, совершенно не заботился о линейной красоте рисунка, но с вдохновением добивался фотоэффекта. Всякого рисовальщика, устремлённого к фотографии, подстерегают разного рода зрительные нелепости. Взглянем на знаменитое Ватиканское «Положение во гроб».

Мускулистые ноги фарисея Никодима кажутся ногами Марии Клеоповой, правая рука которой нелепо венчает голову другой Марии. Ещё более неудачно скомпоновалась рука девы Марии с головой св. Иоанна. Однако именно это произведение Караваджо считается вершиной его творчества. Многие живописцы вдохновлялись этой картиной, например, П. Рубенс и П. Сезанн. Эпикуреец и гедонист Рубенс, полная противоположность кинику и беспощадному реалисту Караваджо, весьма вольно скопировал знаменитое полотно и, заметим, инстинктивно избежал промахов, перечисленных выше. Избежал именно потому, что заботился о плоскостном звучании рисунка, а ещё потому, что был истым художником барокко с его галактическими завихрениями.

Протестант и реформатор Караваджо работал в эпоху маньеризма, стиля католической контрреформации. Элементарные приёмы композиции, наработанные к тому времени, им игнорировались. Характерной для маньеристов взволнованной взвинченности фигур он противопоставляет «естественную» грубоватость. Привычная для реформатора Караваджо композиционная схема такова: на плотно-тёмном прямоугольнике холста резко высвечиваются там и сям фрагменты тел и драпировок. Эти фрагменты выскакивают из темноты настолько спонтанно и несогласованно с краями и углами картины, что ожидать консонанса для глаз не приходится.

Но рядовой зритель так увлечён убедительно резкой лепкой форм, иллюзорностью светотеней, 
жестоким реализмом отрезаемых голов, что готов дать резкую отповедь любой эстетской критике, даже критике самого Никола Пуссена. Так прав или ошибался Пуссен? Неужели он предвидел будущий кризис веризма?

Тут следует напомнить, что европейское изобразительное искусство пережило ряд демократических революций: отказ от Византийской плоскостной системы, караваджизм, камеробскура Фабрицио и Вермеера, реализм Делакруа и изобретение фотографии. Пик веризма наступил одновременно с помпьерами и салоном. Реакция, желание радикальных перемен и стилистического обновления выражались сначала в увлечении японской гравюрой и импрессионизме, потом в дендизме и модерне. Как было сказано выше, в недрах модерна зародился конструктивизм. Увлечение негритянской и океанической скульптурой окончательно сбросило путы реализма. Последовали революции отнюдь не демократические: дадаизм, эстетизировавший абсурд и нелепости разного рода, близкий родственник сюрреализму, метафизикам, футуризму, лучизму; воцарилась деструкция... словом, появились многочисленные и разнообразные виды авангардизма.

Немецкий экспрессионизм очень повлиял на советских художников, особенно графиков, потому что бум ксилографии начала двадцатого века охватил одновременно три революционные страны: Россию, Германию и Мексику. В 1928 году Макс Бэкман, один из ведущих художников немецкого экспрессионизма, опубликовал свои «Шесть сентенций в работе над картиной». Вот два отрывка из этого труда, точно характеризующие его методу: «Изменение оптического ощущения мира объекта с помощью трансцендентной математики души субъекта определяет конструкцию картины...»; «Перевод трёхмерного пространства мира объекта в двухмерное плоскостное в картине - признак настоящей формы...» Но беспредметность, абстракция надолго и деспотически воцарилась в сферах изобразительного искусства, объявляя всякую фигуративность чем-то неприличным.

Такое положение не могло не вызвать ответную реакцию. Из итальянского футуризма произошло протестное движение «Новеченто», а из немецкого дадаизма вылилась «Новая вещественность». Оба течения декларировали культурный национализм, базирующийся на исторических ценностях искусства прошедших веков. Оба эти течения были родителями нашего Соцреализма, мощного стиля, который ошибочно считается достоянием только Советского Союза, тогда как он распространился по всей Европе.

Этот стиль, в свою очередь, высмеивали и профанировали отечественные нонконформисты под бурные аплодисменты «Свободного мира». Все новации андеграундных художников были очень эпигонскими, но они зорко следили за тем, что делается на западе в сфере изобразительных искусств. Всё-таки они внедрили в нашу графику своего рода стиль, который я назвал бы «лохматым». Это сплав из графики Жана Карзу, с его трепещущими движениями пера, из рисунков пером Тадеуша Кулисевича и рисунков Рембрандта. Ярчайшим представителем этого модного стиля был Д. Лион, а сегодня его демонстрируют Ю. Перевезенцев и А. Антонов.

Сегодня мы наблюдаем две главные тенденции мирового рисунка: беспредметность (главным образом американский абстрактный экспрессионизм) и фотореализм. Очень модны грандиозные портреты, нарисованные карандашом с невероятной тщательностью, да так, что каждая пора грубой кожи не ускользнула от назойливого карандаша. Совершенно непонятна утилитарная функция грандиозного рисунка. Неужели Пуссен был прав?

Моё твёрдое убеждение как рисовальщика, не следует стесняться Красоты, трансцендентной, вневременной, даже пафосной Красоты, красоты знания и умного рисунка.

\section{БИБЛИОГРАФИЯ}

1. 1000 Dessins de Genie. - Parkstone International, 2014

2. Ferdinand Hodler. - Fine symbolistische Vision Kunstmuseum Bern. - HATJE CANTZ.

3. Каталог ARSLONGA, Творческий союз художников России; Российская академия художеств. - Издательство «Гайдмарк»: Москва, 2010.

4. Jonathan Hill (2006) Drawing research, The Journal of Architecture, 11:3, 329333, DOI: 10.1080/13602360600931342 (in English)
5. Ihsan Elrabaie (2020) The Graphic Label Was Raised as a Visual Means of Communication to the Values and Behavior of the Individual, International Journal of Art and Art History, 8(1), pp. 1-6. DOI: 10.15640/ijaah.v8n1a1 (in English)

6. Heck, K. 2018. "Buildings, Portraits and Trees. The University Landscape of Greifswald in Pomerania Caspar", Baltic Journal of Art History, vol.16, pp.5-14. DOI: https:// doi.org/10.12697/BJAH.2018.16.01 (in English) 